\title{
Interesting ECG in Critical Care
}

\author{
Sachin Sondhi ${ }^{1 *}$ and Ayushi Mehta ${ }^{2}$ \\ ${ }^{1}$ Department of Cardiology, Indira Gandhi Medical College, India \\ ${ }^{2}$ Department of Anaesthesia, Indira Gandhi Medical College, India
}

Submission: October 27, 2017; Published: December 11, 2017

*Corresponding author: Sachin Sondhi, Senior Resident, Department of Cardiology, Indira Gandhi Medical College, Shimla, Himachal Pradesh, 171001, India, Tel: +91-8219508161; Email: ssachin119@gmail.com

\section{Case Summary}

Hyperkalemia can cause life-threatening arrhythmia, and thus recognizing related patterns on the ECG is crucial. 36 year old female was admitted in ICU with organophosphate poisoning. She was on continuous atropine infusion. She developed paralytic ileus because of prolonged atropine infusion which further led to abdominal compartment syndrome. She went into sepsis and acute renal failure. ABG revealed high anion gap metabolic acidosis and hyperkalaemia. Her serum potassium levels were $8.5 \mathrm{mmol} / \mathrm{l}$. Electrocardiogram characteristically showed tall tented $\mathrm{T}$ waves in precordial leads, absent $\mathrm{P}$ waves, widening of QRS complex and sine wave pattern in limb leads (Figure 1). She developed ventricular fibrillations for which she was 200 joule of unsynchronized shock and given $10 \mathrm{ml}$ of $10 \%$ calcium gluconate and also started on 10 unit of regular insulin with $100 \mathrm{ml}$ of $25 \%$ dextrose infusion. In view of oligouric renal failure and metabolic acidosis, she was given continuous renal replacement therapy.

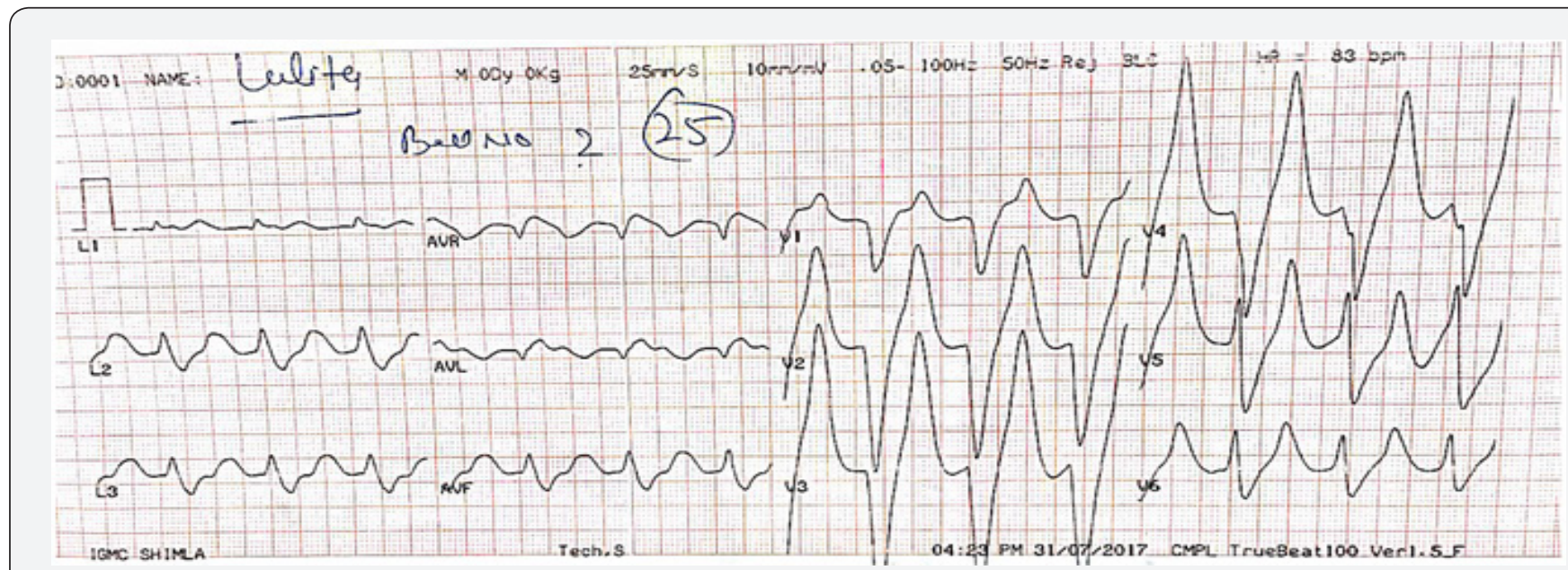

Figure 1: Electrocardiogram showing Hyper acute, tall tented T waves in precordial leads, absent $P$ wave as it merge with $T$ wave, wide QRS and sine wave pattern in inferior leads.

\section{Discussion}

ECG features of hyperkalemia depend on the levels of serum potassium. Tall tented $\mathrm{T}$ waves are seen when serum potassium level is $>5.5 \mathrm{meq} / \mathrm{l}$ followed by widening of $\mathrm{P}$ wave, prolongation of PR segment and then disappearance of $\mathrm{P}$ wave when levels are $>6.5 \mathrm{meq} / \mathrm{l}$. When levels are increased to more than $7 \mathrm{meq} / \mathrm{l}$, then QRS widens and then there is formation of sine wave in ECG [1]. Severe hyperkalemia levels $>9 \mathrm{meq} / \mathrm{l}$ can lead to cardiac arrest due to heart blocks or ventricular fibrillations. When you encounter report with hyperkalemia (serum levels $>5.5 \mathrm{meq} / \mathrm{l}$ ), first you should rule any faulty collection of sample which leads to haemolysis and raised potassium levels [2]. After that look for cause, whether it is due to drugs, cellular redistribution or renal failure and then manages accordingly.

Hyperkalaemia is medical emergency and can lead to ventricular fibrillations, cardiac Asystole or heart blocks. ECG is cost effective investigation to diagnose it [3].

\section{References}

1. Wagner GS, Henry JL, Marriott marriott's practical electrocardiography.

2. Mount DB, Brenner BM (2004) Disorders of potassium balance, in Brenner \& Rector's. The Kidney, ( $7^{\text {th }}$ edn), Saunders, Philadelphia, USA.

3. Nielsen S, Frøkiaer J, Marples D, Kwon TH, Agre P, et al. (2002) Aquaporins in the kidney: From molecules to medicine. Physiol Rev 82(1): 205-244. 
This work is licensed under Creative Commons Attribution 4.0 License

DOI: 10.19080/CTBEB.2017.10.555786
Your next submission with Juniper Publishers will reach you the below assets

- Quality Editorial service

- Swift Peer Review

- Reprints availability

- E-prints Service

- Manuscript Podcast for convenient understanding

- Global attainment for your research

- Manuscript accessibility in different formats

( Pdf, E-pub, Full Text, Audio)

- Unceasing customer service

Track the below URL for one-step submission https://juniperpublishers.com/online-submission.php 